\title{
Literary Parody of Russian Communism Harmonizing to George Orwell's Two Novels "Animal Farm" and "Nineteen Eighty Four"
}

\author{
Hazhar Ramadhan Ahmed \\ PhD Scholar, University of Raparin, College of Basic Education, English Department.(Kurdistan \\ Region, Iraq). \\ hazhar.ahmed@uor.edu.krd
}

\section{Shabana Kausar}

Ph.D Scholar, Lahore College for Women University, Lahore, Pakistan. E_shabana.rehman@lcwu.edu.pk

\section{Othman Saleh Mahdy Mohammed}

Assistant professor, English department, University of Science and Technology. othmanswosabi924@gmail.com

DOI: http://doi.org/ 10.36892/ijlls.v3i2.554

\begin{tabular}{|c|c|}
\hline $\operatorname{Rec}$ & \\
\hline $4 / 04 / 2021$ & $\begin{array}{l}\text { This paper concerns within one of the foremost critical viewpoints in literature, } \\
\text { where the metaphorical and mocking centrality of 'Animal Farm' and 'Nineteen }\end{array}$ \\
\hline $\begin{array}{l}\text { Accepted: } \\
\text { 26/06/2021 }\end{array}$ & $\begin{array}{l}\text { Eighty-Four' by George Orwell is highlighted, Orwell combines political } \\
\text { reason with a creative one to voice his critical conviction. Orwell utilized } \\
\text { parody to grant more impact and understanding of his two books. Animal Farm }\end{array}$ \\
\hline $\begin{array}{l}\text { Keywords: } \\
\text { Literary; } \\
\text { Parody; Russian } \\
\text { Communism, } \\
\text { Harmonizing, Animal } \\
\text { Farm and Nineteen } \\
\text { Eighty Four }\end{array}$ & $\begin{array}{l}\text { is ostensibly an animal story, but deep down it is a moral story, a parody around } \\
\text { the Russian Revolution of } 1917 \text { with wrong qualities of course battle. } \\
\text { Segregation, and fear as superpowers. Eurasia and East Asia are two } \\
\text { superpowers and Oceania, the third one, is continuously at war with one of } \\
\text { them. By using political parody within the two books, the writer makes a consul } \\
\text { and curiously air that influences progressing the plot in arrange to provide a } \\
\text { clear understanding and improving its structure. In arrange to connect the } \\
\text { investigate questions and the discoveries, a nitty-gritty clarification on the } \\
\text { concept of the parody has been displayed as a curiously literary method; } \\
\text { something else, peruses would not discover a relationship between the two } \\
\text { works. At long last, Orwell actually succeeds in encoding his knead within the } \\
\text { shape of a parody and hence peruses associated with him. }\end{array}$ \\
\hline
\end{tabular}

\section{INTRODUCTION}

It is critical to be beyond any doubt that any substance or subject matter, which is in English, can upgrade the learner's capacity in English. Still, literature has an extraordinary ability to do so. The thing that will upgrade the learner's expertise in English is as it were literature. However, it is vital to keep in mind that literature is the reflection, which reflects aesthetically, and respectably the reality in society and enlightens its individuals. In studying literature, one of the foremost perspectives of understanding what has been named as literary gadgets in common. This term in literature is continuously a perplexity for numerous learners, particularly those whose major Literature field. To get it, the literature you would like to consider and get 
it the literary gadgets since it can be the key to memorizing and presently almost the literature world.

This, we must think about Literature and Literary gadgets to attain two points. The primary point ought to be to edify the learners around the life and their societies. The second point is to cultivate the learner's expertise within the English Language. In other words it learner distinctive. It gives learners outstanding abilities that offer assistance to them to get it the branches of the English language such as language structure, etymological semantic, syntactic, and iterative itself. It implies that we must consider literature as a Language aptitude subject that can cultivate the communicative and ideological possibility of the learner.

On the other hand, the concept of literary gadgets ratters to the ordinary structures utilized by scholars in their works to communicate a message to their peruses- a straightforward scholarly way to their reader's scholarly gadgets offer assistance peruses to translate and analyze a scholarly work through literary analysis approach, which suggests that you just are able to get it may and different scholarly devices. Literary devices offer assistance to get it literary such as plot, setting, there, and authors to make meaning full story and novel to upgrade the reason and ordinary meaning or understanding of the subject and plot utilize characters and numerous other techniques.

The authors and writers cannot make their craved work without counting the literary methods in their works. Authors utilize distinctive sorts of literary procedures to make a strong temperament and engage within comes to. They can make the readers intrigued and offer assistance to get it the common thought and ethical. Authors too can make anticipation, which makes a difference the readers to appreciate and total perusing of the story. This inquiries about considered the scholarly strategies utilized in Animal Farm and Nineteen Eighty-four, which is Parody. Parody may be a literary gadget of composing or craftsmanship, which mainly derides its subject regularly as planning implies of inciting or anticipating alter. It is the control of the literary procedure utilized by authors or writers to qualities their plot and covey fantastic subject. This investigation pointed at giving a case of how books, stories, fiction... etc. are analyzed, utilizing literary strategy examination. This investigation centers to consider Animal Farm and Nineteen Eighty Four.

Both texts are composed by Orwell are books that are wealthy in literary gadgets or literary procedure, notably Parody, which is crucial to get two books. Too, it makes a difference for the readers to know the plot and subject of the stories. This creates a difference for readers and familiarizes them with analyzing any literary work with a center on books through theoretical methods analysis.

\subsection{Statement of the Study Articulation of the Investigate}

In considering literature by common, and by the understudies who are majoring within the field, they thought that don't pay consideration to one of the major concepts while examining the literature and the misconception of the literary procedure might make a huge issue to get it and analyze numerous literary works. The investigation is needed to discover multiple groups in the literature that are incapable of exploring a bit of scholarly work such as books, plays, 
brief stories, and composition. The analyst implied in this consider to expound clearly what Parody is in common with a particular center on in italics as two of the Books in which this method implemented and highlight the masterfulness of Orwell as a political essayist. The analyst needed to deliver compositions almost this portion in arranges to bring distinctive thoughts to approximately composing literature.

\subsection{Objectives of the Study}

The investigation's objective is certainly expecting to reply and fathom the research problems expressed over, that's to say; to explain through literary examination how Orwell exceeded expectations within the utilization of Parody as an academic method in Animal Farm and Nineteen Eighty-four. This research needed to expand in detail how Parody was utilized within the two books so that such elaboration is connected to any literary work of literature. In expansion, this inquire about will offer assistance the common and the average readers to get it the art of literature, and how Writers decorate their works employing a Literary strategies such as Parody.

\subsection{The Significance of the Study}

This paper points out how to characterize "Parody" and what work and significance this gadget has by and large in literature to appear how Orwell endeavors to send a message to each society concerning political Parody. In expansion to this, the result anticipated would work to expound clearly, what is Parody as a literary method. To provide the peruses a clear understanding of how Parody was exemplified in Orwell's selected novels, and energize the other readers of literature to center, not as it were on fair perusing for picking up vocabulary and expressions, but understanding the writer's procedures utilized in merging their message powerfully. So the paper shows the literary parody of Russian Communism and points how the author attacks Stalinism and Russian Communism and the life under totalitarian rule.

\subsection{The Methodology of the Study}

The strategy used in planning this paper is the descriptive analysis approach. The instruments used in this paper about collecting information are books, Journals, and Novels as essential sources. The information may well be critically analyzed through the composing of the investigation utilize an analytical approach.

\subsection{Limits of the Study}

The limits of this paper are restricted to Parody as one of the literary strategies utilized in Animal Farm and Nineteen Eighty-four, composed by Orwell, an English author. For the reason of accomplishing the analyst particularly bargain with fair Parody as literary strategies that are utilized to Satirizes the gap society which damaged its perfect and the encourage of control and specialist is additionally Satirized, once the ruler holds the control, pharaoh, Nimrod or Stalin, the reason is same. Animal Farm and Nineteen Eighty Four were literary strategy examinations by expounding how Parody progressed the plot and the subject to communicate the message. The analysts, fair to a lesser amplify clarified two books for accentuation purposes.

\section{REVIEW OF LITERATURE}

\subsection{Foundation of Animal Farm}


A Prize-Winning, Old Mayor in the giant Barn Boar, collects Manor Farm animals for a meeting. He tells them he has a dream that no human being can oppress or control all animals together. He told them to work toward this paradise and taught the animals a song known as "Beasts of England," where he lyrically described his vision of the dream. With great enthusiasm, the animals salute major's vision. Three younger pigs, namely Snowball, Napoleon, and Squealer, formulate their fundamental principles into a philosophy known as Animalism Late one night, the animals planned to defeat the farmer, Mr Jones, in battle and run off the countryside. They rename the Animal Farm property and devote themselves to accomplish Major's dream. The car-horse Boxer is committed to causing particular enthusiasm, devoting its great strength to the farm's prosperity, and adopting the statement "I'll work harder" as a personal maxim.

Animal farm is flourishing at first. Snowball works for teaching the animals to read, and Napoleon takes a group of young puppies to teach them animalism principle. When Jones returns to take up his farm, the animals defeat him again, called in the Battle of the Cowshed, and the abandoned gun of the farmer is a symbol of his victory. As a matter of time, evaluate. Napoleon and Snowball are increasingly challenging over the future of the farm and are fighting for power and influence between the other animals. Snowball creates a system to create a windmill that produces electricity, but Napoleon is firmly against it. Snowball delivers an exciting speech during the meeting about taking up the project. While Napoleon only gives a short report, then he makes an odd noise. Nine attack dogs - Napoleon's puppies confiscated to 'educate' - broke into harm and drove Snowball from the farm. Napoleon takes over the leadership of Animal Farm, declaring that no more meetings will take place. In this regard, he claims, all decisions are made by the pigs alone - for the sake of every animal.

Napoleon is changing his mind quickly about the windmill, and the animals and boxers, in particular, are working towards completing it. The windmill is overthrown once one day after a storm. The farmers in the area are declaring that the walls have become too thin for the animals. But Napoleon claims the windmill was sabotaged by Snowball back to his farm. He is performing an enormous cleansing process. Various animals, supposedly involved in the grand conspiracy of Snowball, which means any animal which is against Napoleon's uncontested leadership, are immediately killed at the dogs' teeth. Unquestioned leadership (Boxer has taken up a second maxim, "Napoleon is always right"). Napoleon begins to increase his authority, rewriting history to make Snowball a villain.. Napoleon begins to behave more and more like a human person, sleeping in a bed, drinking whisky, and trading with nearby farmers. Even though the common animals are cold, hungry, and tired, Squealer, Napoleon's publicist, is making things better for everyone -even though the original Animalist ideals absolutely forbid such activities. (William, 1989; Amenorvi, 2019).

Mr Frederick, a neighboring farmer, defrauds Napoleon of some lumber and then attacks the farm, dynamiting the windmill, which had been rebuilt at a great expenditure. A heated battle unfolds after the windmill is demolished, during which Boxer sustains significant injuries. The beasts annihilate the farmers, but Boxer is rendered helpless due to his injuries. He realizes that his time has come when he stumbles while working on the windmill. Boxer vanishes from the scene one day. Boxer, according to Squealer, died peacefully after being transferred to the 
hospital, applauding the rebellion with his last breath. Napoleon has sold his most devoted and patient employee to a glue manufacturer to get money for whiskey.

Animal farm years pass, and pigs become more and more like men - they walk upright, wear whips and wear clothes. Eventually, the seven animalism principles known as the Seven Commandments are reduced to one principle: "Every animal is equal but some animals are more equal than others. The seven commandments are written down alongside the barns." At dinner, Napoleon hosts a human farm called Mr Pilkington and declares that he intends to form an alliance with the human farmer against workers' classes in human life and animal life. To change the name of Animal Farm back to Manor Farm and claim the title "correct" for the elite Party. The standard animals can no longer tell through the farmhouse window which pigs are and which humans are (Anderson, 1993).

\subsection{Foundation of Nineteen Eighty Four}

In 1984 there are no more methods for accessible business and individual freedom. There are just three superpowers that still dominate a world of hate, isolation, and fear. Two of those superpowers are Eurasia and Eastasia. In contrast, Oceania is always at war with one of these superpowers.

Winston Smith is an employee of 390 years old in the Oceania-based London Ministry of Truth. The Party and its dictator and leader, the "Big Brother" (Big Brother watches you), have shaped his world everywhere in posters titled. Winston's role at the Ministry of the Truth involves revisions of historical documents and news stories to reflect the inability to do so. Big Brother controls Oceania through the four ministries: Peace, Love, Food, and Truth.

The Party that conducts government policies in Oceania provides food, clothing, and social activities. During that latest war, both chocolate and tobacco are lacking. The government issues Winston clothing with its tattered pyjamas, and his nights are spent at meetings sponsored by the government.

War and hate dominate Oceania, where every move and expression is monitored by the Party, including televisions, hidden microphones and spies. The Thought Police, the secret militia of the Big Brother, help the Party soften every sign of revolt and eliminate those who disloyally think or act. Emmanuel Goldstein, the people's enemies, is increasingly devoted to Big Brother during Hate Week. The Party preaches that the proles, the majority, are inferior to their natural condition to be monitored.

But Winston is not totally controlled by the Party. He secretly writes the "Down with Big Brother" illegal diary. In doing so, he commits the worst crime, 'thought crime' and the term Newspeak for the "essential crime that contained all others in it". Many of Winston's thoughts revolve around his attempts to remember different events and people from his childhood, particularly his missing mother. In Winston's efforts, the unique features of all the remains of everyday life in the past have been examined.

In the ministry of truth Winston enters into a relationship with the free-spirited Julia. At first, they see each other's desire as a political act against the hate-dominated Party. Since it was prohibited to promote promiscuity among the party members, they regard their business as a 
rebellion. Winston's feelings for Julia continue to change with the case. However, although the couple knows that the issue is doomed, they still meet Mr.Charrington, the man who sold the diary, and later, a paperweight of corals, secretly in an attic above the junk shop. The lovers talk about repression and the expressed purpose is to overthrow their lives and the expressed purpose is to beat Big Brother.

Winston is approached by O'Brien, who seems to share his opinions at work in the Ministry of Truth. After visiting O'Brien's apartment in Winton and Julia, he recruits them as brothers and sends them a copy of the Goldstein book, detailing strategies to destroy the Big Brother. Winston is committed to doing everything it needs to erode the Party's power, including murder and suicide.

The inevitable thing happens when Julia and Winston have been arrested, treated by Mr. Charrington, a Thought Police member, in their secret room. Winston is taken to the Ministry of Love, wherein the following months he will be hungry, beaten, and tortured to "heal." Ironically, O'Brien is his torturer, who confirms his identity as a dedicated member of the Interior Party. Winston submits to mysterious room 101 after a long flight and threatens him with a cage of hungry rats ready to eat. Finally, he betrays Julia at this point.

Soon Winston is unrestricted, but he anticipates the shot he knows will stub out him. He unpredictably flees into Julia, who confesses that she also had betrayed their love. Astonishingly, Winston feels no longing for her, favoring instead to take his habitual seat at the Chestnut Street Cafe where he passes another night in his usual alcoholic; when telescreen barks the news of the army's latest victory, he weeps with joy. The Party finally gear stick Winston, whose conquest is summed up in the final sentence, "He loved Big Brother".

\subsection{The Political History of English Literature}

Criticism is the most portion of the writing of each country; Scholars need to criticize society too they act like reformers of the society. (Hazhar, 2020a). Composed four diary articles, and he appeared a few fundamental points of feedback within the field of writing in western states and Arabia states, and he clarified how scholars seem to criticize the circumstance of ladies, political issues, and religion. (Hazhar, 2020b,c; Alhashmi, 2020).

"Herbert believes that to define English literature taken as a historic whole and endeavor to define and consider it a port, its character and its changing manifestations Some men of letters approach the study of literature in an a prior fashion. It is a common assumption that acknowledges of political history is essential to a right understanding of literature". (Herbert, 1962, P. 4)

Meyers (1999), states that literature is a mirror that reflects human culture and experiences. It examines all life aspects namely economic, social, psychological, and political dimensions too. Literature is a bridge that shortens the distances among nations and links people to indifferent parts. It contributes to enrich people thinking as well as imagination literature is a culture of people's. (p. 10).

"Orwell, George believes that communism ideology robs Man of his basic human right, namely freedom, justice, and equality. Communism chains humankind's development in many 
walks of life. Since it controls all means of production and thus, deprives lower- classes of promoting their life standards. Orwell. 1945, p.11)."

\subsection{The Russian Revolution}

Janssen, S. states that "There were two Revolutions in 1917. The primary was February, in which the Czarists administration was ousted, and a republic was set up driven by the Doma. The communist ousted the Doma and held races. Lenin did not win the races but seized control besides. In October Revolution, the Bolsheviks battled and crushed the Mensheviks. The Russian Revolution changed Russia's course, causing them to become a superpower, which gave Russia the capacity to change the world. The primary pioneer of the union of Soviet nations was Lenin. Lenin was a solid persuasive, and charismatic leader. He revived the individuals of Russia around him and guaranteed them more uniformity. The individuals of Russia Cherished him even though he ruled for arrange a time. Lenin passed on in 1924; before his death, he warned of future leaders. Lenin defeated resulted in an internal power struggle that Slain won. He succeeded in his position by exiling opponents. He resorted to a series of purge trials, the mass of executions, and exiles to work camps. These strict measures resulted in million deaths based on accounting estimates. (Jansen, 2011, p.667).

\section{DISCUSSION AND ANALYSIS}

\subsection{Communism Parody in Animal Farm}

George Orwell, the author of the tall fashion in parody, composed this tale in the trusts of illuminating not as it were children. Still, moreover, the populace as an entire of his sees on the Russian Revolution and the emergence of Communism in that apportion. The tale, a literary composition passing on an ethical truth, clearly directs the readers to the steps and results of the Russian. Are the creator needs the Russian government through his novel Animal Farm? He assaults Russian Communism. On Stalinism- through a funny and viable animal moral story, Orwell coordinates his political reason with the imaginative reason to voice his cynical conviction, which stems from different encounters he had of transformation, Spain, and the comes about the Russian Revolution framework stays the same. He accepts that it is a dream and thought to assume that individuals can accomplish a classroom society through insurgencies, Rather than the fight being fought and won within the lanes of Russia.

Orwell employments parody is to tell the world what has been happened in Russia's frame of incongruity. So that at the starting of the novel, he depicts the proprietor of House the Farm, Mr. Jones, he had closed the animals up for the proper, but he had not done it appropriately. He was as well drank to keep in mind what to do. Orwell selects to depict the events of the Russian Revolution on a Farm based amid the beginnings of the Mechanical Revolution. The animals, troubled with their daily living circumstances, upsurge, and rebellion against the dictator Jones, the brutal and boozer proprietor of the Jones' Farm. The animals of Mr. Jone's House Farm engaged profoundly by the dreams of life and the anti-human of the convention. As well as the light within the room went out, all the animals have begun to move approximately. They were aiming to have an assembly. Ancient major, as the most seasoned pig, was called, had had an exciting dream the night sometime recently, and he needed to tell the animals all approximately it; they had concurred to meet within the massive horse shelter. 
The Animal Farm, the school building, was a put for the pigs, and seldom other animals, to memorize to read and type in and so develop in social control over the other less-intelligent animals that went through their days working in arrange to bring in sufficient nourishment to keep the revolution lively. The farmhouse was where the Jones family dwelled; sometime recently, the revolution that constrained them astray. According to the commandments set forward after the revolution, no animal was to utilize the farmhouse for their possess individual to pick up, in any case, the pigs were able to mutilate this run the show so that they were able to live in extravagance in this house implied for the people. Building the windmill demonstrated to be an imperative symbol and battle for the animals of Animal Farm. It was eradicated twice and never much-brought happiness.

And the comfortable life of the animals was driven to already and amid the development by the evil pig Napoleon. Each character of Animal Farm spoken to a vital character or sort of individuals within the Russian Revolution a coordinate comparison between animal farm and a solid political development that stunned the world, Comrade Napoleon, as he demanded the other animals called him, speaks to Joseph Stalin, a brutal pioneer amid and the revolution, which ousted other political pioneers and constrained mass executions upon the individuals, fair as Napoleon does in Orwell's tale. Political satire in Animal Farm might be exceptionally cleared and caught on. So that Orwell satirizes the men by calling him a pig and the ways he embraces to bewilder others are too scorns.

The brief novella is a moral story in which animals play the parts of the Bolshevik Revolutions and topple and remove the human proprietors of the farm, setting it up as a commune in which, at, to begin with, all animals are rise to, in any case, lesson and status incongruities before long develop between the distinctive animal species. The novel portrays how a society's belief systems can be controlled and turned by those in social and political control, counting how an idealistic society is made incomprehensible by the undermining nature of the exceptionally control fundamental to make it.

Talking almost Snowball needs more time, the restricting pig, and pioneer of the farm, he spoke to a fair individual. Napoleon ousted him from the Farm and set-off bits of gossip approximately Napoleon's untrue endeavor to eradicate the civilization they had worked to construct after the Revolution; Snowball joins closely with the Soviet exile Leon Trotsky, who was ousted from Russia beneath the dispatch of Stalin. Major was the astute pig that passed absent days after he revealed he arrange for modern and superior life on the farm. It appears to depict characteristics of both Karl Marx and VI Lenin since like this political scholar, major brought around and made the thought of Communism, or "animalism," the Animal Farm form of this framework of thought to assist, its vexed economy and way of life, its individuals were constrained to live out each day. Pilkington and Frederick, the human proprietors of neighboring ranches, speak to different world pioneers amid the time of the revolution, and the events that happened between them and Russia, or between Animal Farm and the other ranchesBoxer, a solid devoted horse of Animal Farm.

The utilization of parody in Animal Farm seems exceptionally clear and equivocal meaning. Orwell makes numerous characters within the story with diverse angles, in expansion. He makes Boxer as a specialist difficult. Real-life Boxer displayed all of the individuals of Russia, 

"Nineteen Eighty Four"

the poverty-stricken, the destitute, who still work hard in arrange to form the framework of communism or animalism work. Boxer represents the specialists who have pushed around, who are taken for all they are commendable, and who are cleared out for dead. "Boxer's split hoof was a long time in healing; they had started the rebuilding of the windmill the day after the victory celebrations were ended. Boxer refused to take even a day off work and made it a point of honor not let it be seen that he was in pain." Orwell, 1945. p.47)

A few days afterward, Squealer declares that Boxer has passed on within the healing center and has been buried in town. He consoles the creatures he was there right at the conclusion, which Boxer passed on saying. "Napoleon is always right." Animal Farm could be a humorous tale set on House Farm; Orwell utilizes purposeful creature anecdote in his assault on Stalinism. Fair as a refresher, parody is "the use of humor, irony, exaggeration, or ridicule to expose and criticize people's stupidity or vices, particularly in the context of contemporary politics and other topical issues." Orwell needed to tell the individuals approximately totalitarianism, so he utilized parody in his stories. The novel is wealthy with satire: the tributes, sonnets, and tunes are all purposeful publicity gadgets. The ceremonies make the laborers increasingly subordinate on administering classes for their character. (William, 1974).

Orwell was an intelligent essayist because time, in Animal Farm, specified how the Animals evacuated Mr. Jones was the proprietor of the House Farm. All animals were prepared to compose the lows of the Farm "Seven commandments." The seven commandments are laws that were assumed to keep arrange and guarantee basic Animalism inside Animal Farm. These Seven Commandments were outlined to join together the animals against people and anticipate creatures. From taking after, the humans' vicious propensities - since not all animals can keep in mind them. They bubble down into one fundamental explanation: "four legs good, two legs bad" (with wings are as legs for this purpose, Snowball in dispute that wings count as they are objects of propulsion rather than manipulation), which the sheep continually reprise, disrupting the crowd from the lies of the begs.

\subsection{Communism Parody in 1984}

George Orwell is one of the most noteworthy authors of political fiction in our time. Orwell centers on the thought of communist, but he was exceptionally basic of Communism and particularly totalitarianism. George Orwell illustrates political parody by overstating the blemishes of dictatorship. The most imperfection of the government framework shown within the novel is the hardship of the flexibility of the citizens of Oceania. Shockingly, the government controlled and upheld its control without giving anybody his right. We knew that the government ought to make individual opportunities accessible. Utilizing political Parody for humor, incongruity embellishment, or scorn to uncover and criticize one's idiocy or indecencies in legislative issues. George Orwell's vision of the world in 1984 diagrams extraordinary totalitarianism; by doing this, he makes the blemish of the government framework apparent "Who controls the past, controls the past".

Within the dystopian desperate; (characterized by human suffering or misery), social orders of Oceania control over the intellect and power over the past are both essential to guarantee control over the populace. At this point, the Party announces the thought that wherever government is in custody at a given time has the power to control everything that's, everything 
that was, and everything that ever will be. One of the techniques of the Party was to change and ruin history. The Party is genuinely effective in that it can influence the show, the past, and the end of the. In other words, one of the issues raised in 1984 is the thought that history is changeable or changeable, that truth is what the party judges are to be, which the facts found in history are the premise of the standards of long-term. A few Rightist German pioneers of the time bragged that if you tell a lie boisterous sufficient and regularly sufficient, individuals would acknowledge it as truth. In 1984 you'll go to find more things that let you baffle almost the cleaning of the society, and you may also go to something that you cannot envision (Wain, 1979).

The Stalinists idealized this modus operandi by rewriting individuals and occasions in and out of history or mutilating verifiable realities to suit the Party's purposes. The thought of controlling can guarantee their specialist. On the political standard, cherish isn't included because it is in Oceania. The portion works to suppress all physical sensations of cherish and depersonalize sex to the point where it is alluded to as a "duty to the party. "Winston endures the Party's evacuation of individual fulfilment or satisfaction in connections is his fizzled marriage with Katharine. Afterward, when he finds Julia, Winston relishes the flexibility of adore somebody physically and in a passionate way. So much of Winston's appearing disobedience turns out to be guided and impacted by the Party.

I cannot predict that controlling people's conduct and behaviors is common, but inside the Party, they ran ordinary. Winston and Julia start a mystery adore. The primary assembly up within the wide-open and after that in a leased room on Mr Carrington's shop is the Prole district. This connection endures a few times; Winston is beyond doubt that they will be caught and rebuffed sooner or afterward, whereas Julia is more practical and optimistic.

Tragically, Winston never finds any bliss fair he gets tormented. Consequently, absent one falls in adore or has sentimental relations, he will be rebuffed, Winston finds that O'Brien, could be a party spy who essentially imagined to be a part of the Brotherhood in arrange to trap Winston into committing an open act of resistance against the Party. The one who wants to cherish the one who is getting to battles in his life, Obrien Cautions Winston that the Party will slaughter him at whatever point it considers is appropriate.

Winston is sent to Room 101, where an individual is confronted with his most prominent fear here at this point Orwell needs to educate society an imperative lesson that how to bargain with the individuals and provide them their rights so that they utilize parody inside 1984 makes from it to be a masterpiece.

Winston calls out, "do it to Julia!" That is pretty much what O'Brien was looking for; So Winston gets to go back to being a happy member of the rat race. The novel portrays the enduring of society amusingly in arrange to form the individuals be mindful of what happened and what will happen within the future time, on the off chance that individuals fair center on the thought of totalitarianism. Orwell's dialog of cherish isn't as it were consigned to sentimental adore. Winston's mother's recollections differentiate between how she cared he and his sister and the normal party family is striking. Winston's mother profoundly loved her 
children and did all she might to secure them amid the repercussions of the transformation and the Party's rise to power.

\section{CONCLUSION}

Literature is one portion that can play a crucial part concerning English Language. We ought to instruct literature to create the learner's stylish and basic sensibility dismiss. It is vital to be beyond doubt that literature gives readers a more extensive creative energy to find the world and see things through their eyes. It is crucial to keep in mind that literature is the reflection, which reflects aesthetically, and respectably the reality in society and enlightens its individuals. We must ponder literature to attain two points. The primary point ought to be to illuminate the learner around life in common, through this point able to know and find more approximately the language.

The moment is to cultivate the learner's expertise within the English Language- literature is curious to common individuals in common and understudies majoring in it in specific. The distinction is that the latter gather ought to get to see literature with a broader sense, that to say; see it literary by way of looking at the inward viewpoints of it, such as understanding why a few literary works are best, what quality makes a few results way better than others. This would take us to a few to what is known as literary analysis and essential investigation of work and the excellence of expressions, which is the most objective of this investigation literature spoken to an enormous umbrella, which is partitioned into numerous branches.

It is subdivided into literary gadgets, literary components, and after that, scholarly strategies. In arrange to learn more about literature, it would be a chance for anybody to get it any literary procedure or any kind of writing like a short story, novel, and dramatization, it makes a difference understudies in this field to the reason of considering and instructing literature and literary strategies. This thinks about appears academic specialist scholarly strategies play a significant part in enhancing this field. The literary procedure is utilized in Animal Farm, and Nineteen Eighty-four is Parody and how Orwell used this procedure in his novel. Behind this idea, we will get that the author of these two books provides a comprehensive picture of society.

He was a great author who utilized various and curious procedures. Particularly the thought of animalism (the teaching or those people are simple Animals, and need any most profound sense of being or delight of physical cravings). Moreover, he centered on stories telling stories about a story instructing approximately great heavier utilizing animals rather than people. Finally, Orwell, too, arranges to improve these two Books, incorporate techniques like Parody to assist him in sending his rub; this procedure made a difference in him ace his books and made him a great and genuine author by genuine activity within Animal Farm. This think analyses Animal Farm and nineteen Eighty-four. It centers on the critical angle of examining literature, that's the literary technique.

\subsection{Recommendations}

1- Literature can offer assistance to an understudy to reinforce his linguistics competencein show disdain toward the fact that the language of literature may be a peculiar one and there's no correct competence. 
2- Lecturers at colleges of literature should heighten their educating strategies, particularly essential considering and literary strategies examination, to prepare the understudies who would major in the field and amplify their capacity to analyze literary works of all genres.

3- There may be a requirement for diligent literary investigation workshops to be carried out as a strategy amid lectures, especially for college understudies who major within the literature field. This thought would familiarize these concerned with the ways to be taken after analyzing literature works, dodge fair perusing for picking up lexicon reason, which most readers do nowadays.

4- Teaching literature ought to be based on a comparative social system. Inside this system, literature can offer precise information approximately Islamic culture in differentiating with outside cultures.

5- Understudies at colleges ought to attempt to form introductions to empower themselves to take unused and cutting edge ways of dialog to improve the level or standard of students.

\section{References}

Alhashmi, R. (2020). The Grotesque in Frankenstein in Baghdad: Between Humanity and Monstrosity. International Journal of Language and Literary Studies, 2(1), 90-106. https://doi.org/10.36892/ijlls.v2i1.120

Amenorvi, C. R. (2019). Exodus In 'Exodus': A Multimodal Analysis of Bob Marley's Lyrics. International Journal of Language and Literary Studies, 1(3), 20-29. https://doi.org/10.36892/ijlls.v1i3.90

Anderson, R. (1993). Elements of Literature. Holt Rine Hart and Winston: Austin. (p.804).

Hazhar, A. (2020a ). The Impersonation of Nature in the Poetic Consonance of Emily Dickinson. .Journal of Arts, Literature, Humanities and Social Sciences, 51, 373_383. https://doi.org/10.33193/JALHSS.51.2020.66

Hazhar, A. (2020b ). Philosophy of Feminism and Suffering of Western Women Concurring to Charlotte Bronte's Novel "Jane Eyre", Journal of Electronic Research Journal of Literature, 2, 45 52. Doi:10.5281/zenodo.4165853

Hazhar, A. (2020d). Poet as a Messenger of Aesthetic among Society, Journal of Arts, Literature, Humanities, and Social Sciences, 48, DOI: 10.33193/JALHSS.48.29

Hazhar, A.(2020c ). The Formularization of the East Simulacrum in the Poetic Consonance of Walter De La Mare, Journal of University of Raparin, 7(1), DOI: 10.26750/Vol(7).No(1).paper29

Herbert, G. (1962). The Background of English Literature. Chatoo and Windus, London.

Jansen, S. (2011). The World.

Meyers, L. (1999). Literary Culture Simon and Schuster j Custom Publishing. New York.

Orwell, G. (1945). Animal Farm. Harcourt Brace Jovanovich, New York. 
Wain, J. (1979). Orwell as a writer of Polemic Prentice Hall: New Jersey. (p.111).

William, K. (1989). Adventures in English Literature. Harcourt Brace. Jovanovich. Orlando.

William, R. (1974). Animal Farm: Collection of Critical Essay New Jersey. Prentice- Hall. (p.110).

\section{AUTHORS' BIO}

Hazhar Ramadhan Ahmed is a Ph.D. scholar of English Language, Lecturer, and Researcher at University of Raparin Kurdistan Region, Iraq. His ranges of inquiring about the interface: English language instructing, linguistics, and literature, moreover has three Recognition Degrees in Islamic sciences, Educating Strategies, and Persian Dialect. Besides, He could be a member of the international federation of Journalists (IFJ), and Reviewer of the Electronic Research Journal of Social science and Humanities in Pakistan. https://orcid.org/0000 000342689056

Shabana Kausar is an assistant professor working in Lahore College for Women University as a visiting faculty. She is working as a PhD weekend coordinator too in Lahore College for Women University, Pakistan . https://orcid.org/0000 000251968973

Othman Saleh Mahdy Mohammed is an assistant professor. He taught several courses such as Phonetics, Introduction to Language, and Pronunciation. He taught English language as a guest lecturer at Coach Challenge Institute, India. His research areas include translation, translation technologies; Computer-assisted Translation, and ELT. Scopus Author ID: 57219415483 and https://orcid.org/0000-0001-5492-4725 